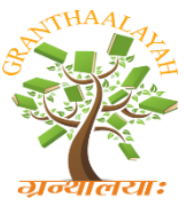

INTERNATIONAL JOURNAL OF RESEARCH GRANTHAALAYAH A knowledge Repository

Social

\title{
ATTITUDE TOWARDS RIGHT TO EDUCATION ACT AMONG HIGHER SECONDARY SCHOOL STUDENTS IN KANYA KUMARI DISTRICT
}

\author{
Velam. T ${ }^{* 1}$, Mrs. S. Anitha ${ }^{2}$ \\ ${ }^{* 1}$ Research Scholar, M.E.T. College of Education, Chenbaharamanputhur, Kanyakumari district, \\ India \\ ${ }^{2}$ Assistant Professor in General Education, M.E.T. College of Education, Chenbaharamanputhur, \\ Kanyakumari district, India
}

DOI: https://doi.org/10.29121/granthaalayah.v5.i3(SE).2017.1925

\begin{abstract}
The investigator was conducted to study the attitude towards right to education act in higher secondary school students in kanyakumari district. The investigator collected data from kanyakumari district higher secondary school students randomly from different schools. The data obtained were analyzed by using appropriate statistical techniques such as mean, standard division, t-test, ANOVA, and level analysis. The findings reveals that there exists significant difference in Gender, Medium of instruction, Type of family and Type of school and there no significant difference in Religion.
\end{abstract}

Keywords: Attitude; School; Education; Students \& Right to Education.

Cite This Article: Velam. T, and Mrs. S. Anitha. (2017). “ATTITUDE TOWARDS RIGHT TO EDUCATION ACT AMONG HIGHER SECONDARY SCHOOL STUDENTS IN KANYA KUMARI DISTRICT." International Journal of Research - Granthaalayah, 5(3)SE, 7-12. https://doi.org/10.29121/granthaalayah.v5.i3(SE).2017.1925.

\section{Introduction}

Education is the back bone of a nation. The aim of education is expected aspirations of a society as well as its lasting values. The aim of education serves as broad guidelines to align educational process to choose ideal and accepted principles. We would need to ensure that the aim of education is reflected in curriculum, syllabus, textbooks and other learning materials developed by us. Therefore an intelligent society will always invest in quality education for its children and youth. 


\section{Need and Significance of the Study}

This study is very significant as this provides an insight into the status of implementation of RIGHT TO EDUCATION in schools, awareness and understanding of the provisions of Right to Education among teachers and parents of children studying in the elementary school. The issues and challenges raised in the study will help all the stake holders to become aware of their rights, take an active role in the enforcement of these rights and implement this Act more effectively and fruitfully to have a better quality Education Act.

\section{Right to Education in India}

At present there are five articles in the constitution of India which have children as their special focus. These articles are Article 21A, 24, $39 \& 45$ and 51A (k). Thus special provisions for children find place in our constitution in fundamental rights, Directive principles as well as fundamental duties.

\section{Education in the Indian constitution}

Indian Constitution contains a preamble, 22 schedules, 12 Appendices and 395 Articles. The fourth schedule in the constitution deals with the 'Directive guidelines for the government to frame its polices. The seventh schedule of the constitution lists the education responsibilities of the central legislature of each of the states and all local authorities within the territory of India or under the control of government of India.

\section{Article 46}

Promotion of Educational and economic Interests of weaker sections of society.

\section{This article states}

The State shall promote with special care the educational and economic interests of the weaker sections of the people and in particular of the scheduled lasts and the scheduled Tribes and shall prate it them from social injustice and all forms of exploitation. It could be noted that no one could not approach the court for the enforcement of those auricles mentioned in the fourth schedule.

\section{Review of Related Literature}

Sarika Malik (2013) has conducted a study on "Awareness of Right to Education Act among Prospective Teachers". The study examined to find out the level of awareness of rural and urban prospective teachers about Right to Education. The findings of the study revealed that the urban and rural prospective teacher's ratio is high; there is necessity to develop the awareness towards RIGHT TO EDUCATION, which in turn helps them to develop the same among their students.

Gadam (2013) has conducted a study on "Teacher Awareness of the Responsibility under Right to Free and Compulsory Education Act". The study examined the impact of working experience of teacher on their awareness of the responsibility under right to free and compulsory education act and to study the impact of educational qualification of teachers on awareness of the responsibility. The findings of the study revealed that there was significant impact of teacher's 
working experience on their awareness of the responsibility under RIGHT TO EDUCATION Act, 2009. Those teacher's working experience is high his/her awareness of the responsibility under the Right to Free and Compulsory Education Act is high and those teacher's working experience is low his/her awareness of the responsibility under the Right to Free and Compulsory Education Act is also low. There is significant impact of the educational qualification of the teacher on their awareness of the responsibility under RIGHT TO EDUCATION Act, 2009. Those teacher's educational qualification is high his/her awareness of the responsibility under Right to Free and Compulsory Education Act is high and those teacher's educational qualification is low his/her awareness of the responsibility under Right to Free and Compulsory Education Act is low

Fathima Jaseena (2011) has conducted a study on "Right to Education-A Study on the Awareness of M.Ed. Trainees" The study to find out the awareness of M.Ed. students about right to education and to study the effect of gender, type of management of the institution on the awareness of Right to Education Act, 2009. The findings of the study revealed that male M.Ed. students possess significantly higher awareness about the Right to Education Act, 2009 than the female M.Ed. students. And the type of management of the M.Ed. College did not have any effect on the awareness of the Right to Education Act, 2009.

\section{Statement of the Problem}

The investigator has selected the problem "Attitude towards Right to Education Act in Higher Secondary School students in Kanyakumari District”.

\section{Operational Definitions}

\section{Right to Education Act}

The Right to Education Act is an Indian Legislation enacted by the Parliament of India on $4^{\text {th }}$ August 2009.The Act describes the moralities of the importance of Free and Compulsory Education for children between the age of 6 to 14 in India under Article 21 A of the Indian Constitution.

\section{Higher Secondary Students}

The students refer to the children who are studying in XI and XII school students in Kanyakumari district.

\section{Objectives of the Study}

- To find out the level of attitude towards Right to Education act of higher secondary school students.

- To study the significant difference between the mean scores of right to education act based on the background variables namely gender, medium of instruction and type of family.

- To study the significant difference among the mean scores of right to education act based on the background variables namely religion and type of management. 


\section{Hypotheses of the Study}

- The attitude towards Right to Education act of higher secondary school students is at moderate level.

- There is no significant difference between the mean scores of Right to Education Act based on the background variables namely gender, medium of instruction and type of family.

- There is no significant difference among the mean scores of Right to Education Act based on the background variables namely religion and type of management.

\section{Methodology}

\section{Method}

The investigator adopted normative survey method of research to study the problem.

\section{Population}

The population of the present study consisted of all the higher secondary school students of the various schools located in Kanyakumari district.

\section{Sample}

The sample of the present investigation included 400 higher secondary school students from various schools of education located in Kanyakumari district.

\section{Tools}

Right to Education Act test (Developed by the investigators)

\section{Statistical Techniques Used}

The collected data were analyzed by using statistical techniques like percentage analysis, mean, standard deviation, t-test and ANOVA.

\section{Results and Discussion}

The results of the analysis are presented in the following tables.

\section{Hypothesis testing using level analysis \\ Hypothesis 1:}

The attitude towards Right to Education act of higher secondary school students is at moderate level.

Table 1: Data and results of Level Analysis of higher secondary school students in their attitude towards right to education

\begin{tabular}{|l|l|l|l|}
\hline \multicolumn{1}{|c|}{ Variable } & Groups compared & N & Percentage \\
\hline Right to education Act & Low & 74 & 18.4 \\
\cline { 2 - 4 } & Medium & 225 & 56.3 \\
\cline { 2 - 4 } & High & 101 & 25.3 \\
\cline { 2 - 4 } & Total & 400 & 100 \\
\hline
\end{tabular}


Table 1 showed 18.4 percent of attitude towards Right To Education Act among higher secondary school students have low, 56.3 percent of them have medium and 25.3 percent of them have higher levels of attitude towards Right To Education.

\section{Hypothesis testing using t-test}

\section{Hypothesis 2:}

There is no significant difference between the mean scores of right to education act based on the background variables namely gender, medium of instruction and type of family.

Table 2: Comparison of mean scores of Right to Education Act based on background variables namely gender, medium of instruction and type family

\begin{tabular}{|c|c|c|c|c|c|c|}
\hline Variables & Category & $\mathbf{N}$ & Mean & SD & $\mathbf{T}$ & $\begin{array}{c}\text { Level of } \\
\text { significance }\end{array}$ \\
\hline \multirow{2}{*}{ Gender } & Male & 158 & 104.04 & 14.350 & \multirow{2}{*}{7.606} & \multirow{2}{*}{0.05 level (S) } \\
\hline & Female & 242 & 93.02 & 13.864 & & \\
\hline \multirow{2}{*}{$\begin{array}{l}\text { Medium of } \\
\text { instruction }\end{array}$} & Tamil & 313 & 100.49 & 14.836 & \multirow{2}{*}{2.022} & \multirow{2}{*}{0.05 level (S) } \\
\hline & English & 87 & 96.79 & 15.833 & & \\
\hline \multirow{2}{*}{$\begin{array}{l}\text { Type of } \\
\text { family }\end{array}$} & Joint & 103 & 93.85 & 13.284 & \multirow{2}{*}{4.653} & \multirow[t]{2}{*}{0.05 level (S) } \\
\hline & Nuclear & 297 & 74.3 & 74.3 & & \\
\hline
\end{tabular}

Table 2 reveals that obtained t- value of attitude towards right to education act among higher secondary school students is greater than the table value based on their gender medium of instruction and type of family. It also showed that the higher secondary school students differed significantly at 0.01 level based on their gender, type of family and 0.05 level in their medium of instruction. Hence the null hypotheses are not accepted.

\section{Hypothesis testing using ANOVA}

\section{Hypothesis 3:}

There is no significant difference among the mean scores of Right to Education Act based on the background variables namely religion and type of school.

Table 3: Comparison of mean scores of Right to Education Act based on background variables namely religion and type of school

\begin{tabular}{|c|c|c|c|c|c|c|}
\hline Variables & Category & Sum of Squares & df & Mean Square & $\mathbf{F}$ & $\begin{array}{c}\text { Level of } \\
\text { Significance }\end{array}$ \\
\hline \multirow{2}{*}{ Religio } & Between group & 447.988 & 2 & 223.994 & \multirow{2}{*}{0.978} & \multirow{2}{*}{$\begin{array}{l}\mathbf{0 . 0 5} \\
\text { (NS) }\end{array}$} \\
\hline & Within group & 90962.322 & 397 & 229.124 & & \\
\hline \multirow{2}{*}{$\begin{array}{l}\text { Type of } \\
\text { school }\end{array}$} & Between group & 5487.524 & 2 & 2743.762 & \multirow{2}{*}{12.677} & \multirow{2}{*}{$\begin{array}{l}\mathbf{0 . 0 5} \\
(\mathbf{S})\end{array}$} \\
\hline & Within group & 85922.786 & 397 & 216.430 & & \\
\hline
\end{tabular}


Table 3 reveals that obtained F- value of attitude towards Right to Education Act among higher secondary school students is greater than the table value based on their religion and type of school. It also showed that the higher secondary school students not differed significantly at 0.05 level based on their religion. Hence the null hypothesis is accepted. It also showed that the higher secondary school students differed significantly at 0.05 level based on their type of school. Hence the null hypothesis is not accepted.

\section{Findings of the Study}

- The attitude towards Right to Education Act of higher secondary school students is at moderate level.

- There is no significant difference between the mean scores of Right to Education Act based on the background variables namely gender, medium of instruction and type of family.

- There is no significant difference among the mean scores of Right to Education Act based on the background variables namely religion.

- There is significant difference among the mean scores of Right to Education an Act based on the background variables namely type of management.

\section{Conclusion}

The above study reveals that overall attitude towards Right To Education Act among higher secondary school students is of moderate level. It also reveals that the t-test, ANOVA, have revealed that there exists significant difference in Right to Education Act among higher secondary school students with respect to the back ground variables like gender, medium of instruction, type of family and type of management, there was no significant difference in religion.

\section{References}

[1] Agarwal, J,c. development and planning of modern education, Vikash publishing house, new delhi, 1990.

[2] Ahmed, F., RIGHT TO EDUCATION Act 2009 and sociological apprehensions, Jamia journal, 2012.

[3] Amar upadhya, Niakhisenapati. Implementation of RIGHT TO EDUCATION Act 2009 in the elementary schools of assam, EDU TRACK, 15(8).

[4] Golden, S. A. R. (2011). Problems and Prospectus of Distance Education. Quality Enhancement In Distance Education For Life Long Learning, 1(1), 343-344.

[5] Golden, S. A. R. (2016). RURAL STUDENTS' ATTITUDE TOWARDS ENGLISH AS MEDIUM OF INSTRUCTION IN HIGHER EDUCATION - AN ANALYSIS. International Journal of Research, 3(Special Issue - 16), 1-10.

[6] Golden, S. A. R. (2017). Recent Research In Social Science \& Humanities.

[7] Sharma,R., and saini, R. (2012).Implementation of RIGHT TO EDUCATION Act, 2009 in rural India.International Referred Research Journal, 3 (29).

[8] Uma,(2013). Right to education (RIGHT TO EDUCATION): A critical Appraisal IOSR Journal of Humanities and social science (JHSS), 6(4). 